\title{
Severe pneumonia after intravesical $B C G$ instillation in a patient with invasive bladder cancer: case report and literature review
}

\author{
G. Caramori1, D. Artioli1, G. Ferrara2, R. Cazzuffi ${ }^{1}$, C. Pasquini1, \\ M. Libanore3, V. Guardigni3, I. Guzzinati ${ }^{1}$, M. Contoli ${ }^{1}$, R. Rossi4, \\ R. Rinaldi5, C. Contini 3 , A. Papi 1
}

\begin{abstract}
Severe pneumonia after intravesical BCG instillation in a patient with invasive bladder cancer: case report and literature review. G. Caramori, D. Artioli, G. Ferrara, R. Cazzuffi, C. Pasquini, M. Libanore, V. Guardigni, I. Guzzinati, M. Contoli, R. Rossi, R. Rinaldi, C. Contini, A. Papi.

We present here the case of a 66 year old man with a severe bilateral community acquired pneumonia secondary to dissemination after an intravesical instillation of bacilllus Calmette-Guérin (BCG). Diagnosis was based on
\end{abstract}

positive polymerase chain reaction (PCR) for mycobacterium tuberculosis complex in bronchoalveolar lavage and on the finding on transbronchial biopsy of non necrotising granulomas histopathologically similar to the granulomas found in bladder biopsies. These findings were confirmed using a validated real time PCR assay demonstrating the presence of the BCG genome in transbronchial and bladder biopsies.

Monaldi Arch Chest Dis 2013; 79: 1, 44-48.

Keywords: Bladder carcinoma, Bacilllus Calmette-Guérin (BCG) immunotherapy, Pneumonia, CAP.

1 Sezione di Malattie dell' Apparato Respiratorio, Centro per lo Studio delle Malattie Infiammatorie Croniche delle Vie Aeree e Patologie Fumo Correlate dell'Apparato Respiratorio (CEMICEF), Dipartimento di Scienze Mediche, University of Ferrara, Italy.

2 Lung Allergi Kliniken, Karolinska University Hospital, Stockholm, Sweden.

3 Sezione di Malattie Infettive, Dipartimento di Scienze Mediche, University of Ferrara, Italy.

4 Microbiology Department, Arcispedale S. Anna, Ferrara, Italy.

5 Sezione di Anatomia-Patologica, Dipartimento di Morfologia, Chirurgia e Medicina Sperimentale, University of Ferrara, Italy.

Correspondence: Prof. Gaetano Caramori MD, PhD, Centro per lo Studio delle Malattie Infiammatorie Croniche delle Vie Aeree e Patologie Fumo Correlate dell' Apparato Respiratorio, Università di Ferrara, Via Savonarola 9, 44121 Ferrara, Italy; e-mail: gaetano.caramori@unife.it

This work has been funded by Fondo di Ateneo per la Ricerca (FAR 2009, 2010, 2011) (ex 60\%) Università di Ferrara (to GC).

\section{Case Report}

Sixty-six year old man, former smoker of 30 pack/year, in good health until 2007. In this year he was diagnosed with in situ papillary urothelial bladder cancer of high grade and then treated once weekly for six weeks every year, from 2007 to 2010, with intravesical instillations of bacillus Calmette-Guérin (BCG). In May 2010, during an intravesical instillation of $\mathrm{BCG}$, the traumatic catheterization procedure caused local pain and a gross hematuria. The same day the patient reported onset of fever and dysuria. An Urological Consultant suggested starting antibiotic treatment with ciprofloxacin (500 mg twice daily per os) and ceftriaxone (1 gram once daily intramuscularly). After two days because of the persistence of high fever and the onset of dyspnea at rest, the patient went to the Emergency Room of our hospital where a chest radiograph showed the presence of bilateral pulmonary opacities (fig. 1A). For this reason the patient was evaluated by a Pulmonologist and a consultant in Infectious Diseases and discharged home with the same antibiotic therapy. However three days after the patient went back to the Emergency Room because of worsening dyspnea and was admitted to our Respiratory ward because of the presence of acute respiratory failure with respiratory alkalosis. At the admission in our ward the patient was severely dyspnoeic at rest. He had bibasilar crackles on chest examination without other signs. A chest radiograph suggested a significant increase in the number and extension of the bilateral pulmonary opacities. A computed tomography (CT) scan of the chest with contrast excluded the presence of pulmonary embolism but showed the presence of bilateral ground glass opacities and thickened interlobular septa with crazy-paving pattern (fig. 1B). Broad spectrum intravenous antibiotic therapy [clarithromycin (500 $\mathrm{mg}$ twice daily), amikacin (1 gram once daily), ciprofloxacin (400 mg twice daily) and cef- 


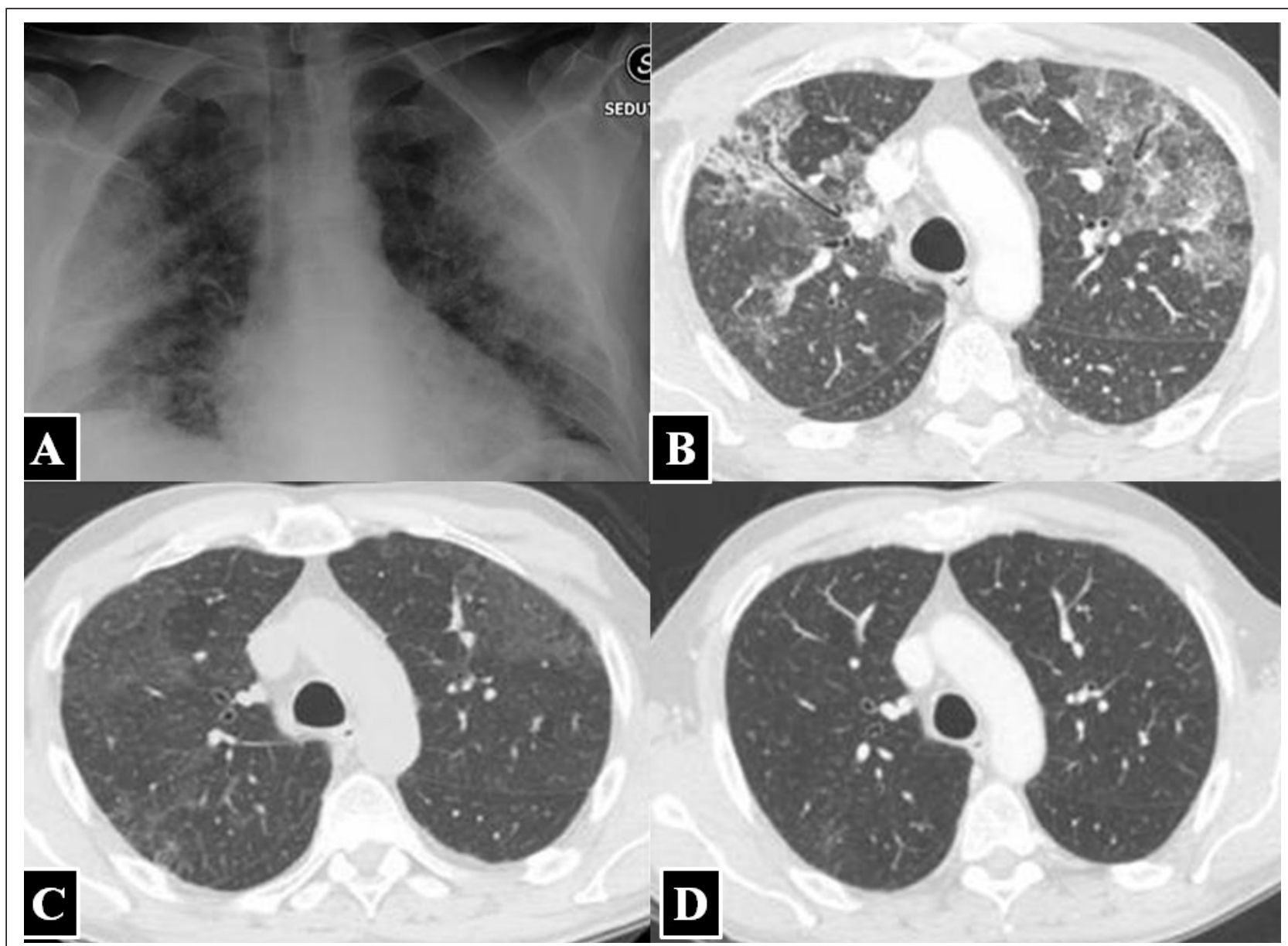

Fig. 1. - (A) Radiography of the chest performed in the Emergency ward showing the presence of bilateral pulmonary opacities. Computed tomography scans of the chest obtained respectively after one day of admission in our ward of Respiratory Diseases (B), after one month of antitubercular therapy while the patient was hospitalized at Infectious Diseases department (C) and after five months of therapy (D).

tazidime (2 grams thrice daily)] and intravenous methylprednisolone (40 mg once daily) were immediately started. On the third day after the admission the fever and the acute respiratory failure disappeared whereas the lung opacities were unmodified after a week of therapy. A fiberoptic bronchoscopy was performed showing no any sign of gross lesions in the central airways, a transbronchial biopsy sample was sent for pathological analysis and a broncho-alveolar lavage (BAL) for microbiology and cytopathological analysis was performed. A quantiFERON ®-TB GOLD ELISA was negative. Acid-fast stains and cultures (on sputum, urine and blood) were negative for bacteria, mycobacteria and fungi. After nine days the patient was moved to the Infectious Diseases ward for the presence in the BAL of positive polymerase chain reaction [AMPLICOR Mycobacterium tuberculosis Test (Roche Diagnostic Systems, USA)] for Mycobacterium tuberculosis complex whereas BAL culture was negative. An abdominal ultrasound examination was negative except for the presence of slight hepatomegaly and two benign cysts in the liver and kidney. Another chest radiography showed little changes in the pulmonary opacities. The pathological examination of the transbronchial biopsy revealed the presence of fibrosis and chronic interstitial inflammation with small non-necrotizing granulomas containing giant cells (fig. 2A). Acid-fast organisms were ab- sent. Similar lesions were observed in a bladder biopsy performed in the same patient two years before due to a suspicion that bladder cancer had recurred and attributed at the time to local inflammation secondary to the BCG therapy (fig. 2B). The presence of $\mathrm{BCG}$ genome in both transbronchial and bladder biopsies was confirmed using an in house validated real time PCR assay (fig. 2C, D) [1]. Standard anti-tubercular treatment was started per os with isoniazid (300 mg once daily); rifampin (600 mg once daily), ethambutol (1500 $\mathrm{mg}$ once daily) and pyrazinamide (1500 mg once daily) associated with a seven days course of intravenous methyl-prednisolone $(20 \mathrm{mg}$ once daily). Due to the occurrence of major hepatic side effects (ALT and $\gamma$-glutamyl-transpeptidase increase 3 times over the normal range), isoniazid, rifampin and pyrazinamide were discontinued and replaced by streptomycin (1 gram once daily intramuscularly) and levofloxacin (1 gram once daily per os) followed by progressive normalization of the serum level of these enzymes. After one month of therapy a new CT scan of the chest demonstrated the partial resolution of the lung opacities (fig. 1C). After 30 days by its introduction streptomycin was replaced with rifabutin ( $450 \mathrm{mg}$ once daily per os), whereas ethambutol and levofloxacin were continued. A CT scan of the chest, performed after 5 months of therapy showed almost complete resolution of the lung opacities (fig. 1D). The patient 

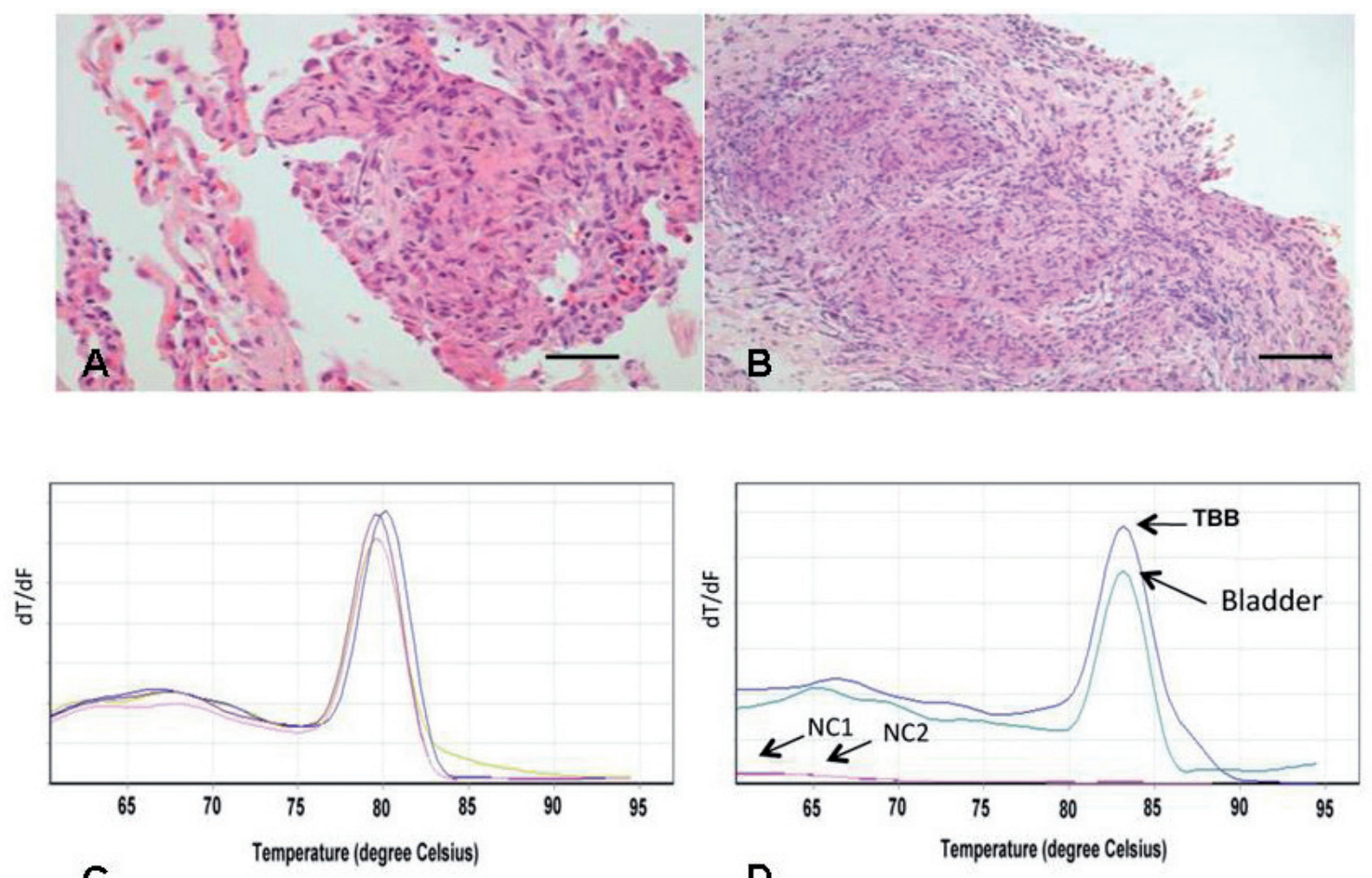

Fig. 2. - (A) Transbronchial biopsy showing the presence of non-necrotising granuloma with giant cells, which were also present in a bladder biopsy of the patient performed two years before (B) [hematoxylin and eosin stain, both at 200x magnification]. The scale bar represents 50 um. In house real-time PCR assay for the presence of BCG genome: Panel (C) amplification of beta actin DNA (loading control) in both transbronchial and bladder biopsies from the patient and in the peripheral lung, obtained during lung resection for lung carcinoma, from two negative control patients. Panel (D): presence of RD1 deleted only in the DNA extracted from the transbronchial (TBB) and bladder biopsies from the patient without its presence in the DNA obtained from the peripheral lung of the two negative control patients.

completed 9 months of treatment overall, switching to two drugs (rifabutin and levofloxacin) only after 4 months from the beginning of the therapy. No sign of relapse were observed after the completion of treatment.

\section{Discussion}

We report here the fifteenth published case (on table) of community-acquired pneumonia caused by a disseminated BCG infection secondary to intravesical instillation of BCG immunotherapy for bladder cancer in adult patients. The appearance of the symptoms were strictly related to a minimal invasive procedure (bladder catheterization and instillation of BCG) complicated by gross hematuria. The onset of the radiological findings was also initially interpreted as pneumonia somehow related to the intervention. Interestingly, a AMPLICOR-MBT test gave a positive result on BAL samples, and this triggered the isolation of the patient in an infectious diseases ward and the start of an anti-tuberculosis treatment. Infection by $M$. $t u$ berculosis complex var. hominis could have been bona fide excluded because of the negativity of the Quantiferon TB test and by the appearance of the granulomatous lesions in the biopsies. Furthermore investigations demonstrated for the first time the presence in both transbronchial and bladder biopsies of the patient the presence of the BCG genome using a validated real time PCR assay based on the presence of a genomic region termed RD1 deleted (absent in all the other species of M. tuberculosis complex) in all the BCG strains [1].

As previously reported acid fast stains are instead often negative in these cases as well as caseous necrosis is usually absent (table 1). The result of the in house method used in this report were controlled and their validity is strengthened by the fact that similar amplification products were obtained on the biopsies showing a similar pathological pattern.

The therapy of these disseminated BCG infections is mainly empirical, based on data from case series and expert opinion and includes a combination of antituberculous medications associated with systemic glucocorticoids (usually $40 \mathrm{mg}$ of prednisone daily, gradually tapered over 4-6 weeks) in the most severe cases, as in our patient [2]. In vitro $\mathrm{BCG}$ is susceptible to most antituberculous drugs, including isoniazid, rifampin, ethambutol, fluoroquinolones, clarithromycin, some aminoglycosides, and doxycycline. Usually both isoniazid and rifampin are recommended as first therapeutic approach. However, if the patients treated with isoniazid and rifampin develop serious side effects or drug allergies, ethambutol and fluoroquinolones can be used as alternative treatments [14]. To prevent the dissemination of BCG after its intravesical therapy the administration of 


\begin{tabular}{|c|c|c|c|c|c|c|}
\hline Reference & $\begin{array}{l}\text { Age, gender and } \\
\text { smoking history }\end{array}$ & $\begin{array}{l}\text { Microbiological } \\
\text { diagnosis }\end{array}$ & $\begin{array}{l}\text { Lung } \\
\text { pathology }\end{array}$ & $\begin{array}{l}\text { Chest } \\
\text { imaging }\end{array}$ & Treatment & Outcome \\
\hline 2 & 57 , male, ns & $\begin{array}{l}\text { Culture } \\
\text { (M. bovis) }\end{array}$ & $\begin{array}{l}\text { Non caseating } \\
\text { granulomas }\end{array}$ & $\begin{array}{l}\text { Miliary } \\
\text { pattern }\end{array}$ & $\begin{array}{l}\text { INZ, RIF, PZA, } \\
\text { ETM, systemic } \\
\text { glucocorticoids }\end{array}$ & Resolution \\
\hline 3 & $\begin{array}{l}\text { 57, male, } \\
\text { non-smoker }\end{array}$ & $\begin{array}{l}\text { Acid fast } \\
\text { stain }\end{array}$ & $\begin{array}{l}\text { Non caseating } \\
\text { granulomas }\end{array}$ & $\begin{array}{l}\text { Miliary } \\
\text { pattern }\end{array}$ & $\begin{array}{l}\text { INZ, RIF, PZA, } \\
\text { ETM, systemic } \\
\text { glucocorticoids }\end{array}$ & Resolution \\
\hline 4 & 73 , male, ns & nd & nd & $\begin{array}{l}\text { Miliary } \\
\text { pattern }\end{array}$ & $\begin{array}{l}\text { Antitubercolar } \\
\text { treatment }\end{array}$ & Resolution \\
\hline 5 & 61 , male, ns & All negative & $\begin{array}{l}\text { Non caseating } \\
\text { granulomas }\end{array}$ & $\begin{array}{l}\text { Bilateral } \\
\text { pulmonary } \\
\text { opacities }\end{array}$ & $\begin{array}{l}\text { Antitubercolar } \\
\text { treatment }+ \\
\text { systemic } \\
\text { glucocorticoids }\end{array}$ & Resolution \\
\hline 6 & 75 , male, ns & All negative & $\begin{array}{l}\text { Granulomatous } \\
\text { pneumonia }\end{array}$ & $\begin{array}{l}\text { Miliary } \\
\text { pattern }\end{array}$ & INZ, ETM, RIF & Resolution \\
\hline 7 & 76 , male, ns & nd & nd & $\begin{array}{l}\text { Miliary } \\
\text { pattern }\end{array}$ & $\begin{array}{l}\text { Antitubercolar } \\
\text { treatment }\end{array}$ & Resolution \\
\hline 8 & 60 , male, ns & All negative & $\begin{array}{l}\text { Non caseating } \\
\text { granulomas }\end{array}$ & $\begin{array}{l}\text { Miliary } \\
\text { pattern }\end{array}$ & $\begin{array}{l}\text { INZ, RIF, ETB, } \\
\text { PZA, systemic } \\
\text { glucocorticoids }\end{array}$ & Resolution \\
\hline 9 & $\begin{array}{l}69, \text { male, } \\
\text { current } 40 \text { (p-y) }\end{array}$ & All negative & $\begin{array}{l}\text { Non caseating } \\
\text { granulomas }\end{array}$ & $\begin{array}{l}\text { Miliary } \\
\text { pattern }\end{array}$ & $\begin{array}{l}\text { INZ, RIF, ETM, } \\
\text { PZA }\end{array}$ & Resolution \\
\hline 10 & 71 , male, ns & All negative & $\begin{array}{l}\text { Non caseating } \\
\text { granulomas }\end{array}$ & $\begin{array}{l}\text { Miliary } \\
\text { pattern }\end{array}$ & $\begin{array}{l}\text { INZ, RIF, ETM, } \\
\text { systemic } \\
\text { glucocorticoids }\end{array}$ & Resolution \\
\hline 11 & 76 , male, ns & All negative & $\begin{array}{l}\text { Caseating } \\
\text { granulomas }\end{array}$ & $\begin{array}{l}\text { Miliary } \\
\text { pattern }\end{array}$ & INZ, RIF, ETM & Resolution \\
\hline 12 & 72 , male, ns & $\begin{array}{l}\text { PCR } \\
\text { (M. tuberculosis } \\
\text { complex) }\end{array}$ & ns & $\begin{array}{l}\text { Miliary } \\
\text { pattern }\end{array}$ & $\begin{array}{l}\text { INZ, RIF, ETM, } \\
\text { systemic } \\
\text { glucocorticoids }\end{array}$ & Resolution \\
\hline 13 & 75 , male, ns & $\begin{array}{l}\text { PCR } \\
\text { (M. tuberculosis } \\
\text { complex) }\end{array}$ & $\begin{array}{l}\text { Diffuse } \\
\text { inflammator } \\
\text { signs }\end{array}$ & $\begin{array}{l}\text { Miliary } \\
\text { pattern }\end{array}$ & $\begin{array}{l}\text { INZ, RIF, ETM, } \\
\text { systemic } \\
\text { glucocorticoids }\end{array}$ & Deceased \\
\hline 14 & 62 , male, ns & Acid fast stain & $\begin{array}{l}\text { Necrotizing } \\
\text { granulomas }\end{array}$ & $\begin{array}{l}\text { Miliary } \\
\text { pattern }\end{array}$ & INZ, RIF & Resolution \\
\hline 15 & 70, male, ns & All negative & $\begin{array}{l}\text { Non caseating } \\
\text { granulomas }\end{array}$ & $\begin{array}{l}\text { Reticulo- } \\
\text { nodular } \\
\text { pattern }\end{array}$ & $\begin{array}{l}\text { INZ, RIF, ETM, } \\
\text { pyridoxine } \\
\text { systemic } \\
\text { glucocorticoids }\end{array}$ & Resolution \\
\hline $\begin{array}{l}\text { Abbreviati } \\
\text { PCR = pol } \\
\text { Obtained v }\end{array}$ & $\begin{array}{l}\mathrm{ETM}=\text { ethambu } \\
\text { rase chain reacti } \\
\text { the data from ref }\end{array}$ & $\begin{array}{l}\text { INZ = isoniazid } \\
\text { Id: not done; PZ } \\
\text { ces [2-15]. }\end{array}$ & $\begin{array}{l}=\text { not done; ns } \\
\text { pyrazinamide; }\end{array}$ & secified. & $\mathrm{IF}=$ rifampin. & \\
\hline
\end{tabular}

quinolones (such as ofloxacin and prulifloxacine) has been proven effective in small studies $[16,17]$. This prophylactic antibiotic therapy has not been given to our patient after his last BCG instillation, despite him having described to the nurse a traumatic intravesical catheterisation, but he had taken for five days ciprofloxacin (500 $\mathrm{mg}$ bid) after the onset of fever, before being admitted to our hospital. There is a complete absence of studies on the immunopathogenesis of CAP secondary to disseminated BCG infection in adults. Individuals with impaired cell mediated immunity exhibit in- 
creased susceptibility to infections caused by poorly pathogenic mycobacteria (non-tuberculous mycobacteria and BCG), as well as salmonella species. However, these infections may also occur in a disseminated, fatal form, sometimes with familial distribution, in the absence of any recognised primary or secondary immunodeficiency. Genetic analysis of these families has recently defined mutations in many different genes of the interleukin 12 (IL-12)-dependent, interferon gamma (IFN- $\gamma$ ) pathway [18]. Interestingly all previous cases of disseminated BCG infection after intravesical BCG immunotherapy for bladder cancer described in the literature (table 1) occurred in males, suggesting, despite the concomitant 3:1 male-tofemale ratio for urothelial tumours, a potential influence of sex hormones in this susceptibility. In conclusion, CAP secondary to disseminated BCG infection is a rare complication of intravesical BCG immunotherapy for bladder cancer but additional studies are necessary to better understand its pathogenesis and to standardise the diagnosis and treatment.

\section{References}

1. Pinsky BA, Banaei N. Multiplex real-time PCR assay for rapid identification of Mycobacterium tuberculosis complex members to the species level. J Clin Microbiol 2008; 46: 2241-2246.

2. McParland C, Cotton DJ, Gowda KS, Hoeppner VH, Martin WT, Weckworth PF. Miliary Mycobacterium bovis induced by intravesical bacille Calmette-Guérin immunotherapy. Am Rev Respir Dis 1992; 146: 1330-1333.

3. Palayew M, Briedis D, Libman M, Michel RP, Levy RD. Disseminated infection after intravesical BCG immunotherapy. Detection of organisms in pulmonary tissue. Chest 1993; 104: 307-309.

4. Jasmer RM, McCowin MJ, Webb WR. Miliary lung disease after intravesical bacillus Calmette-Guérin immunotherapy. Radiology 1996; 201: 43-44.

5. Naoki K, Yamaguchi K, Soejima K, A, et al. A case of interstitial pneumonia induced by intravesical administration of bacillus Calmette-Guerin (BCG).Nihon Kyobu Shikkan Gakkai Zasshi (Japanese) 1997; 35: 1383-1388.
6. Iantorno R, Nicolai M, Storto ML, et al. Miliary tuberculosis of the lung in a patient treated with bacillus Calmette-Guerin for superficial bladder cancer. $J$ Urol 1998; 159: 1639-1640.

7. Barankiewitz I, Manor H, Strauss S. Miliary lung disease induced by intravesical Bacillus Calmette-Guérin treatment. Eur Radiol J 1999; 9: 1933.

8. Rabe J, Neff KW, Lehmann KJ, Mechtersheimer U, Georgi M. Miliary tuberculosis after intravesical bacille Calmette-Guérin immunotherapy for carcinoma of the bladder. Am J Roentgenol 1999; 172: 748-750.

9. Audigier C, Nesme P, Perol M, Guerin JC. Rare pulmonary complication in intravesical BCG treatment. Rev Mal Respir 2000; 17: 679-681.

10. Namen AM, Grosvenor AR, Chin R, et al. Pulmonary infiltrates after intravesical bacille Calmette-Guerin: two cases and review of the literature. Clin Pulm Med 2001; 8: 177-179.

11. Mignon F, Chevrière A, Mesurolle B, El Hajam M, Morel H, Lacombe P. Miliary induced by intravesical BCG immunotherapy for carcinoma of the bladder: CT Findings. J Radiol 2002; 83: 368-371.

12. Toscano Rico M, Machado J, Cardoso O, Salvado C, Rodrigues P, Proença R. Severe disseminated tuberculosis after intravesical instillation of Bacillus CalmetteGuérin. Eur J Clin Microbiol Infect Dis 2003; 22: 447 448.

13. Del Castillo Duran Y, Santos Bodí F, Castander Serentill $\mathrm{D}$, et al. [Tuberculosis miliar in a patient treated with intravesical instillations of bacillus CalmetteGuérin]. Med Intensiva 2006; 30: 116-119.

14. Nadasy KA, Patel RS, Emmett M, et al. Four cases of disseminated Mycobacterium bovis infection following intravesical BCG instillation for treatment of bladder carcinoma. South Med J 2008; 101: 91-95.

15. Eccles SR, Mehta R. Disseminated BCG disease: a case report. Respir Med CME 2011; 4: 112-113.

16. Colombel M, Picard A. Prevention of Bacillus Calmette-Guérin immunotherapy complications. Prog Urol 2008; 18 (suppl 5): S105-S110.

17. Rafailidis PI, Polyzos KA, Sgouros K Falagas ME. Prulifloxacin: a review focusing on its use beyond respiratory and urinary tract infections. Int $J$ Antimicrob Agents 2011; 37: 283-290.

18. Patel SY, Doffinger R, Barcenas-Morales G, Kumararatne DS. Genetically determined susceptibility to mycobacterial infection. J Clin Pathol 2008; 61: 10061012.

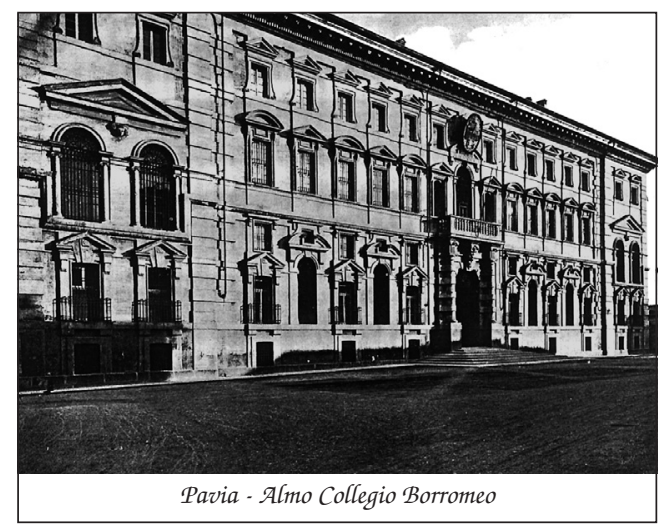

